camouflage organization. Serving officers required for camouflage duties should be seconded to it for training. The sub-committee states that the Ministry of Supply and the Admiralty have no research staff of their own and rely largely on the Ministry of Home Security's establishment. The sub-committee does not regard this as satisfactory. Recalling that two members who have great practical knowledge resigned from the Advisory Committee on Camouflage, the sub-committee is unable to acquit the camouflage departments of a certain degree of neglect of the knowledge and research placed at its disposal by members of the committee (see NATURE of June 22, p. 949). A new committee was formed afterwards.

The testimony of departmental witnesses with the longest experience of camouflage of all kinds was emphatic that specimens of camouflage of fortified posts throughout the country are absurd and cannot be regarded as camouflage at all. The responsibility for these works rests with the Home Forces and the staff of camouflage officers attached to corps and divisions. The sub-committee attributes such errors to the hitherto insufficient number of these officers. It learns, however, that the number has recently been increased. Cases have been brought to the notice of the sub-committee where private practitioners have undertaken the camouflage of industrial premises. Some of these attempts have been futile and might be dangerous. The sub-committee learns with satisfaction that most of these private firms have gone out of existence since the beginning of the War. An Admiralty witness informed the subcommittee that camouflage of ships at sea has been abandoned. In its conclusion, the sub-committee says that the defence of this country so far as camouflage is concerned is a single problem. All schemes of camouflage should be considered as part of a general picture.

\section{Medicine in War-time}

Owrvg to the War, many medical men are cut off from access to journals dealing with their special subjects and from all foreign periodicals. Changed conditions of war may give rise to new problems. The Medical Research Council has therefore undertaken to issue a Bulletin of War Medicine, containing abstracts of papers from both British and foreign sources. This Bulletin is to supply information, not only to specialists, but also to practising medical officers. It is intended to cover all branches of medicine that can apply to war conditions, but not those concerned more intimately with tropical diseases, or matters of purely public health interest, abstracts of which are already available in the Bulletin of Tropical Diseases and Bulletin of Hygiene. The work of searching literature and abstracting suitable papers has been entrusted to the staff of the Bureau of Hygiene and Tropical Diseases.

The first number of the new Bulletin, which is dated September, contains sixty-three papers. Twelve deal with surgery of special regions, nine with general diseases and eight with aviation medicine. Among the subjects dealt with are blood transfusion (eleven abstracts), shock (five abstracts), the use of sulphanilamide and similar preparations (six abstracts) and civil evacuation (five abstracts). Two abstracts only deal with food in war-time. The abstracts are thorough ; in many cases it would be unnecessary for the reader to refer to the original article for further details. It is proposed to issue the Bulletin every two months; besides being distributed to medical officers of the fighting services and the emergency medical service, the Bulletin is being placed on sale (London: H.M. Stationery Office $2 s .6 d$. net.).

\section{Mr. J. B. Priestley's "Postcripts"}

IT is given to few to provide such a complete interpretation of the spirit of Great Britain as Mr. J. B. Priestley has achieved in the 'postscripts' which he has broadcast regularly during recent months. His has been the authentic voice of the country, whether in expressing the courage, resolution and good humour with which the people are meeting the challenge and dangers that ${ }^{\circ}$ confront us, or in voicing the passionate desire and determination to be found in all sections of the population that the sacrifices now being made shall issue in a new order, to be shared by men of good will everywhere, from which the grosser injustices and inequalities of the past have been eliminated. Scientific workers will share to the full the general regret at Mr. Priestley's announcement of the termination of these broadcasts, much as they will respect the reasons which have led him to that decision. All who have enjoyed these broadeasts can best show their appreciation by the wholeheartedness with which they address themselves to the tasks of reconstruction already to hand, the extent and urgency of which has been the theme of many recent articles in NATURE.

\section{Fitness in Industry}

Fitness in industry is of primary importance to the nation, and nothing that will contribute to the good health and high morale of industrial workers should be neglected. Not the least important of its applications is the provision of the tonic effects of natural sunshine by artificial means (welfare solaria). A letter recently communicated to the Press by Mr. F. J. Pascoe, director of British Timken Ltd., describes some of the activities of his company in this direction. The Company's welfare ideas are based on years of experiment, and are not a product of present emergency conditions. The blackout, the seven-day week and night shifts deprive workers of sunlight. The Timken works produce artificial sunlight treatment. These works are large, and elaborate arrangements are justified. Suitable equipment is attainable comparatively cheaply for smaller works, but treatment must be regular and carried out under qualified supervision and in accordance with carefully prepared plans. The Timken Co. has a medical man in frequent attendance, and treatment is administered by a qualified nurse. This treatment has been found to be definitely beneficial to the workers. Short-wave 
therapy apparatus is used for treating septic wounds and skin troubles met with in the industry. For a small works this apparatus is somewhat costly, but the results obtained in a relatively short time are astonishing. Treatment should be given under medical supervision.

Eyesight is of vital importance in quick and accurate production. Free eyesight tests by the visiting doctor costs the Company little and is a help to the workers. Footwear is a problem. A girl worker standing most of the day on concrete floors in thin high-heeled shoes will take very serious toll of her staying power. This is a most neglected point ; workers' footwear should be stout and in good repair. Rubber soles, except in certain types of factories, should be prohibited. The Timken Co. purchases wooden shoes (sabots) which the girls buy at half their cost to the Company. Smoking is allowed. Some works cannot do this, but where it is allowable it does help. One very strict rule, rigidly enforced, is that there must be no smoking in the half hour before people knock off; the reason for this is that fires caused by cigarette ends nearly always show within that time. Music in working hours is beneficial. The Company has had long experience of this, and broadcasts records in two sessions each day to quiet shops where work is of a monotonous nature. One class of music is given in each session-waltzes or marches ; mixing the different classes of music upsets rhythm. Vocal records are never broadcast; light classical music is broadcast at meal times. For A.R.P. shelters stirring choruses are used. Works canteens are sometimes dingy. There is no reason for this. Paint is cheap and pleasing and decorative ideas are even cheaper. A woman's ideas will soon brighten the canteen. Preparation and choice of food for the workers should be as earefully planned as the production in the factory.

\section{Control of Wild Life}

For various reasons in the national interest, a number of official decisions have recently been made to limit the numbers of certain species of British fauna, which in some cases will check the results of protective legislature and private efforts at conservation in the past decade. The Air Ministry has authorized the taking or the destruction of peregrine falcons or their eggs in certain areas including Ayrshire and Dumfriesshire in Scotland and a ten-mile deep area along the Kent and Sussex coasts in England, because of the risk of these falcons attacking carrier pigeons. A deer controller has been appointed to reduce the numbers of wild red deer in Lakeland and north Lancashire, where in recent years these animals have spread from the forest of Martindale and as a result of crossbreds with escaped hinds carted for hunting. A deer controller was appointed for a similar purpose with the Scottish deer forests last year. An Order prohibiting the use of any land for the artificial hatching and rearing of pheasants except under licence-which is chiefly granted to certain game farms where the birds are to be reared for food-does not include partridge and wild duck, but a recent inquiry by the Gamekeepers' Association to the Ministry of Agriculture elicited the information that an Order is contemplated prohibiting the rearing of all game for sporting purposes, and another prohibiting the use of feeding stuffs to game birds, except under licence. For the time being, this means the end of artificial encouragement of game birds and the complicated upsetting of the balance of Nature which it entails in the countryside.

\section{Dr. Christian Fenger}

Dr. Christran Fenger, the first teacher of pathology in the Middle West and an eminent Chicago surgeon, was born on November 2, 1840, at Copenhagen, where he qualified in 1876. He then went to Egypt, where he became a member of the Sanitary Council and surgeon to the Khalifa in the Cairo district. In the following year he settled in Chicago, where he was appointed consulting surgeon to the Cook County Hospital and lecturer on surgery to the College of Physicians and Surgeons. His postmortem examinations and surgical clinics henceforward became the centre of postgraduate instruetion in Chicago. During the thirty years of his professional life he contributed more than eighty articles to surgical literature, his chief work being connected with cancer of the stomach, hernia of the brain, the ball-valve action of floating gall-stones, the operative treatment of cerebral abscesses and the surgery of the ureters and bile-ducts. He died on March 7, 1902. After his death the Christian Fenger Memorial Association was founded under the auspices of the Chicago Medical Society and published his collected works in two large volumes.

\section{All-Electric Laundry}

ST Gabriel's LAUNDRY, of which an illustrated account is given in the Electrical Review of October 11 , is the first all-electric establishment of its kind in Eire. It serves Athlone and the surrounding region and belongs to Sisters of Mercy, one of whose main activities is the domestic training of girls. Originally all the work was done by hand, water being carried from the River Shannon. In 1907, a steam engine and washing machines were installed. Recently, the laundry has been completely electrified, resulting in greater cleanliness and better working conditions. Belt-drive and shafting have been eliminated, and there has been a consequent all-round improvement. In the new wash-house there are three large washing machines supplied directly with water at $180-200^{\circ} \mathrm{F}$., as required, from two 700-gallon storage electric water-heaters which feed the washing machine, rinsing troughs, soap boilers, starch emulsifier, etc. The water is heated at night so as to get the advantage of the cheap rate.

The utilization of electricity has greatly simplified the blueing and starching process. In the case of most of the work coming to the laundry, washing, blueing and starching processes are carried out without the clothes leaving the washing machine. Four methods of drying are available, three of them 